\title{
Editorial - Brexit and the Future of European Legal Studies
}

\author{
Kenneth A ARMSTRONG
}

Editor-in-Chief

The outcome of the United Kingdom's referendum held on 23 June 2016 on whether to remain in, or to leave, the European Union was, for many unimaginable. For those leading the campaign to leave the EU, the result took many of its own supporters by surprise. Not in their dreams could they imagine that the momentum which palpably had been building would ultimately deliver a vote in favour of the UK's withdrawal from the EU. For those who campaigned for the UK to remain in the EU, the outcome was even more unimaginable. That the UK would reverse the decision it made in 1972 to join the then European Economic Community - a decision endorsed in a referendum in 1975 - seemed remote.

The UK's new Prime Minister, Theresa May has announced that 'Brexit Means Brexit'. This statement is intended to dampen calls for a second referendum or a general election, and to fill the political void between the outcome of the referendum result and the triggering of Article 50 TEU to begin the process of withdrawal. Legal challenges in the UK courts may not derail Brexit but they will add to the delay in the UK notifying the European Council of its intention to withdraw. All of which is providing convenient legal cover for politicians and political institutions to ready themselves for the complex and uncertain process of negotiating the UK's departure from the EU.

Where then does Brexit leave European Legal Studies (ELS)? The more pessimistic commentators view the UK's withdrawal from the EU as the beginning of the end for the EU. If correct, ELS will be reduced to a legal history of a form of regional integration that in the end, proved obsolete rather than obstinate. In the absence of that scenario, Brexit may have surprising potential to animate ELS as a field of study.

Never has the demand for legal expertise been higher as attention turned to understanding how the Article 50 TEU withdrawal process might work and what 'constitutional requirements' needed to be met before the UK notified its intention to withdraw. But looking beyond the immediacy of the referendum aftermath, Brexit is an opportunity to understand and analyse how law shapes different models of cooperation among European states (and not just EU member states) and between the EU and so-called 'third countries'. Many of us are being forced to admit that our knowledge of the operation of the European Free Trade Association and its relationship with the EU through the European Economic Area agreement might have been a little hazy. Meanwhile, external relations law and EU trade law are being thrust to the forefront of attention as scholars rush to see what can be learned from the Canada-EU free trade agreement. 
Yet in these terms, ELS is limited to the study of European trade relationships. While that may chime with certain British inclinations towards a form of European 'market membership' in opposition to 'ever closer union', it brackets off other dimensions of the experience of law in Europe. If the EU treaties are indeed more than an agreement between states, and also confer rights on individuals which form part of their legal heritage, then reducing ELS to a form of economic trade law would be to ignore a significant human dimension to the story of legal change in Europe. Indeed, it would be paradoxical if the movements of people around Europe - often cited as a prime cause of anxiety about the demands of EU membership - and the legal effects such migration produces, were to be anywhere other than at the heart of ELS.

If Brexit gives us pause to reflect on the material content of the law to be studied the 'LS' - it more dramatically demands us to respond to what we mean by 'Europe' the 'E' of ELS. If we stand back from the hubris of treating the EU as a synonym for Europe, and of valorising European Union law over other sources of law, legal doctrine and legal value within Europe, then ELS can genuinely claim to be a field of study that offers the potential for an analysis of law in multiple locations within an expansive European legal landscape. The point is not that scholarship has ignored the domestic and comparative dimensions of the 'Europeanisation' of law. It hasn't. And the law of the European Convention on Human Rights has hardly been a neglected field of study. But, much like 'EU law', there has always been the tendency for these fields of study to be studied apart and to be disseminated through distinctive streams of academic publishing in specific journals. Brexit is unlikely to change that in any dramatic way but it can be taken as an opportunity to re-imagine what we think can count as appropriately 'European' for the purposes of European legal scholarship.

For the Cambridge Yearbook of European Legal Studies, our central mission has been to offer authors and readers a space for sustained reflection, and conversation, about the challenges facing Europe and the diverse legal contexts in which those challenges are addressed. In the years ahead we will publish on the unfolding legal dynamics of Brexit, but in the context of a renewed commitment to a broad and inclusive approach to ELS. The articles featured in this year's volume reflect that open approach and future volumes will also continue to reflect the diverse nature of ELS as a field of legal scholarship.

In its eighteenth volume, the Yearbook continues to develop its readership online and in print, and now also through its social media presence on Twitter (@CY_ELS). The editors are always happy to discuss ideas for contributions and can be contacted either via Twitter or by email at CYELS@law.cam.ac.uk. As ever, the editors are grateful to the professionalism of Sally Thomas in copy-editing the articles and to Sue Tuck and Rebecca O'Rourke at Cambridge Journals for their support of our work. As a publication of the Centre for European Legal Studies, the editors also owe an enormous debt of gratitude to Felicity Eves-Rey in managing the work of the Centre including the Yearbook. 